\title{
A CONFIGURAÇÃO TERRITORIAL DA CAJUCULTURA CEARENSE: uma análise dos circuitos espaciais da produção e os círculos de cooperação da cajucultura no município de Pacajus
}

\author{
THE TERRITORIAL CONFIGURATION OF CASHEW \\ PRODUCTION IN CEARÁ: an analysis of the spatial circuits of \\ production and the cooperation circles of the cashew production in the \\ municipality of Pacajus
}

\begin{abstract}
Kailton Jonatha Vasconcelos Rodrigues
Mestre pelo Programa de Pós-Graduação em Geografia (PROPGEO) da Universidade Estadual do Ceará (UECE) e membro do Laboratório de Estudos Agrários, Urbanos e Populacionais (LEAUP), Fortaleza, CE, Brasil kailtonjonathan@hotmail.com

Denise Cristina Bomtempo

Professora Adjunta dos cursos de Graduação em Geografia e do Programa de Pós-Graduação em Geografia (PROPGEO) da Universidade Estadual do Ceará (UECE). Coordenadora e Pesquisadora do Laboratório de Estudos Agrários, Urbanos e Populacionais (LEAUP), Fortaleza, CE, Brasil denise.bomtempo@uece.br
\end{abstract}

\section{Resumo}

A cajucultura é uma das principais atividades econômicas do Ceará, sendo atualmente a terceira maior pauta de exportação do estado. Diante desta visibilidade, faz-se necessário compreender como funciona sua lógica, bem como a configuração territorial do seu circuito produtivo, que engloba atividades referentes à produção agrícola, à industrialização, à comercialização de produtos advindos da fruta, a exemplo da amêndoa da castanha (ACC), óleos vegetais (LCC), sucos e a cajuína. Nesse sentido, o presente texto pretende analisar a cajucultura a partir de sua configuração territorial, ação dos agentes envolvidos no setor, bem como, seus fluxos, e a configuração dos circuitos espaciais da produção unidos aos círculos de cooperação, cujas atividades se desenvolvem por meio dos processos relativos ao desenvolvimento, à produção e à comercialização dos produtos oriundos da amêndoa da castanha (ACC) e do pedúnculo do caju, além das relações para com o mercado interno e externo. A opção empírica pelo município de Pacajus, no Ceará, deu-se devido à presença constante de todos os elementos supracitados, que se desenrolam no município e arredores. Desse modo, Pacajus permite compreender as dinâmicas e ao mesmo tempo fazer a síntese dos fenômenos e processos que envolvem a cajucultura empreendida no estado do Ceará.

Palavras-chave: Cajucultura. Circuitos espaciais da produção. Círculos de cooperação. Pacajus. 
A configuração territorial da cajucultura cearense: uma análise dos circuitos espaciais da produção e os círculos de cooperação da cajucultura no município de Pacajus
Kailton Jonatha Vasconcelos Rodrigues Denise Cristina Bomtempo

\section{Abstract}

Cashew is one of the main economic activities of Ceará, and is currently the third largest export tariff in the state. In view of this visibility, it is necessary to understand how its logic works, as well as the territorial configuration of its productive circuit, which encompasses activities related to agricultural production, industrialization, and commercialization of fruit products, such as chestnut almonds, vegetable oils, juices and cashew nuts. In this sense, the present text intends to analyze cashew based on its territorial configuration, action of the agents involved in the sector, as well as its flows, and the configuration of the production space circuits united to the circles of cooperation, whose activities are developed through of the processes relating to the development, production and marketing of cashew nut (ACC) and cashew peduncle products, as well as relations with the domestic and foreign markets. The empirical option by the municipality of Pacajus, in Ceará, was due to the constant presence of all the aforementioned elements, which unfold throughout the territory of the municipality and its surroundings. In this way, Pacajus allows to understand the dynamics and at the same time to synthesize the phenomena and processes that involve the cashew undertaken in the state of Ceará.

Keywords: Cashew production. Production space circuits. Circles of cooperation. Pacajus.

\section{Introdução}

O presente artigo pretende delinear uma discussão acerca do circuito espacial de produção e círculos de cooperação atrelados ao cultivo de caju no município de Pacajus, estado do Ceará. Para tanto, o ponto de partida é compreender a configuração territorial, bem como as atividades econômicas de maneira geral e, em particular, as múltiplas configurações da cajucultura materializadas nas paisagens do município em apreço, como também no cotidiano da população. Vale ressaltar que para estruturação deste texto, utilizamos do referencial teórico, como também do levantamento de dados secundários, mas a verificação empírica, definitivamente, validou as descobertas e a interpretação do objeto.

Mudanças de natureza técnica e política acarretam uma elevação significativa dos fluxos internacionais. A inerente conexão mantida entre as perspectivas neoliberais, a proeminência da financeirização, seja de caráter público ou privado, e o crescimento das tecnologias da informação e comunicação, na perspectiva do capital, resultam na progressiva mundialização da produção, dos serviços e do consumo. Relaciona-se a 
A configuração territorial da cajucultura cearense: uma análise dos circuitos espaciais da produção e os círculos de cooperação da cajucultura no município de Pacajus
Kailton Jonatha Vasconcelos Rodrigues Denise Cristina Bomtempo

gradativa difusão territorial das fases produtivas, resguardadas por maior associação operacional e de coordenação. Como afirma, Bomtempo (2011):

[...] sistemas técnicos informacionais permitiram a conformação de redes, e com isso a mobilidade do capital, das empresas e da força de trabalho não ficou restrita apenas a uma escala geográfica, pelo contrário, a divisão territorial do trabalho, a partir da configuração do meio técnico-científicoinformacional abarcou a escala planetária. (BOMTEMPO, 2011, p. 178).

Diante do apresentado, tal encadeamento redireciona a atribuição mantida pelos lugares, antes apenas articulados a escalas locais e regionais. "A instalação de novos equipamentos vinculados à economia mundo permite aos lugares a ampliação de papéis, tanto na divisão territorial do trabalho, como também na rede urbana em que está inserido e que mantém relações" (BOMTEMPO, 2011, p. 54). Este aspecto permeia as relações que se estruturam adiante, ao modificar e alterar a percepção e a concepção do território.

Nesse contexto, de acordo com Bomtempo e Silva (2018), no período atual o território se conforma e imprime a necessidade de leitura de elementos tradicionais e novos que coexistem. Assim, compreender o território pressupõe percebê-lo enquanto uma síntese dialética da ordenação global e da mentalidade local que coadunam.

De modo geral, a dispersão e das atividades econômicas no território, permite entender a conformação de circuitos espaciais da produção mais complexos. Essa realidade se faz presente na configuração dos circuitos espaciais produtivos da cajucultura cearense, já que esta atividade, traduz-se num fenômeno que atinge várias categorias de relações ao se materializarem nas abundantes localizações geográficas que circunscrevem o território. É possível observar a difusão do capital articulado ao segmento da cajucultura intentando exercer uma política normativa ao território ao passo em que percorre e utiliza o mesmo, conforme uma lógica que é global disposta sob uma força de caráter local.

A pesquisa que desenvolvemos intentou compreender estes processos, que segundo Castillo e Frederico (2010, p. 464) “[...] envolve a circulação de fluxos materiais (mercadorias, pessoas) pelo espaço e estes se associam aos fluxos imateriais ou círculos de cooperação (capital, informação, normas) ao realizar seu processo circulatório e articulado". Dessa forma, o conceito de circuito espacial da produção serve de base teórica para trabalhar diferentes segmentos da economia espacial. 
A configuração territorial da cajucultura cearense: uma análise dos circuitos espaciais da produção e os círculos de cooperação da cajucultura no município de Pacajus
Kailton Jonatha Vasconcelos Rodrigues Denise Cristina Bomtempo

Vale ressaltar que os circuitos espaciais da produção não se consolidam isoladamente, faz-se necessário compreender, inclusive, o papel desempenhado pelo conjunto dos fixos e fluxos, bem como das redes. Entende-se como fixos as estruturas que compõem tudo que permanece imóvel no espaço, como estradas e infraestruturas, de modo que "[...] permitam ações que modificam o próprio lugar, fluxos novos ou renovados que recriam as condições ambientais e as condições sociais, e redefinem cada lugar" (SANTOS, 1988, p. 75). Enquanto que os fluxos podem ser categorizados em materiais e imateriais, são por sua vez constituídos por meios que possuem mobilidade ou que podem atuar em espaços diversificados, deste modo "[...] os fluxos são um resultado direto ou indireto das ações que atravessam ou se instalam nos fixos, modificando a sua significação e o seu valor, ao mesmo tempo em que, também, se modificam" (Santos, 1988, p. 75), o espaço, por sua vez, é alterado significativamente em virtude das constantes interações mantidas entre fixos e fluxos, originando um emaranhado de relações que culminam no surgimento de inúmeras redes.

Do mesmo modo, os círculos de cooperação, surgem como um elemento que proporciona a articulação de todas as fases dos circuitos, conforme apontam Castillo e Frederico (2010), tais círculos, tratam das comunicações, informações e ordens (fluxos imateriais), organizados de tal maneira que possibilitam a interação e articulação entre os lugares e agentes dispersos geograficamente, unificados através de comandos centralizados.

\section{Pacajus: configuração territorial e atividades econômicas}

O município de Pacajus está localizado no estado do Ceará, mais precisamente na região metropolitana, a $51 \mathrm{~km}$ de distância da capital do estado, Fortaleza. A unidade territorial do município corresponde a uma área de 254, $636 \mathrm{~km}^{2}$, tendo em sua composição uma predominância da área rural, além da sede urbana que dá nome ao município. A seguir é possível observar no mapa 1, a localização de Pacajus. 
A configuração territorial da cajucultura cearense: uma análise dos circuitos espaciais da produção e os círculos de cooperação da cajucultura no município de Pacajus
Kailton Jonatha Vasconcelos Rodrigues Denise Cristina Bomtempo

Mapa 1: Pacajus - Mapa de localização

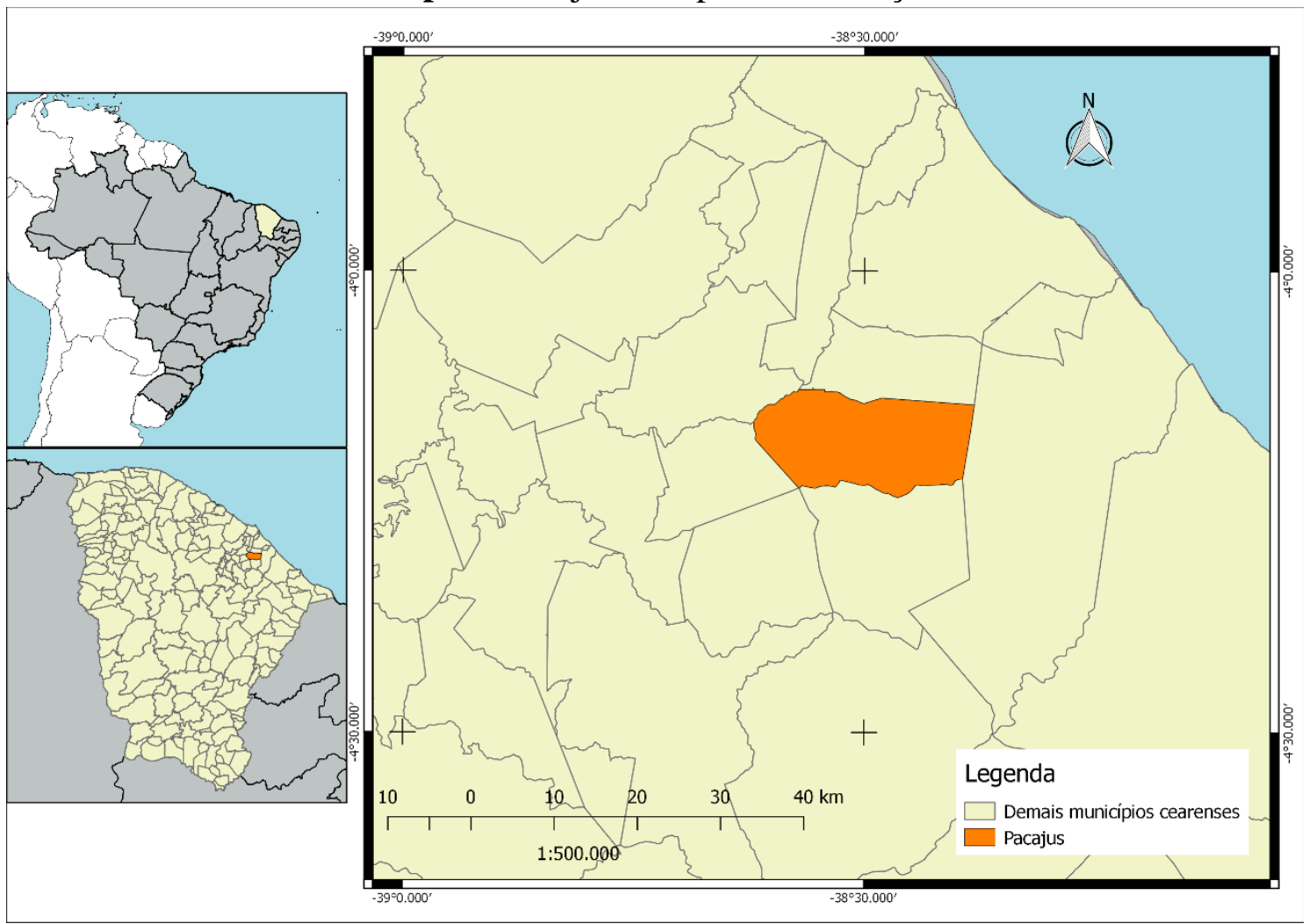

Org.: RODRIGUES, Kailton Jonatha Vasconcelos, 2018.

Conforme os dados disponibilizados pelo IBGE em 2017, o município possui uma população residente estimada em 70.911 pessoas, com uma densidade demográfica equivalente a 243,00 habitantes por $\mathrm{Km}^{2}$, o que lhe assegura a $22^{\mathrm{a}}$ posição no ranking dos municípios mais populosos do estado do Ceará. Pacajus também se destaca enquanto uma potencial economia do estado, com um PIB nominal em 2015, proporcional a $\mathrm{R} \$$ 938.848,49. Desse valor, 4\% correspondem à agropecuária, 29\% a indústria e 35\% aos serviços. Nesse contexto, a atividade que mais se destaca é o comércio, mas a rentabilidade advinda do cultivo do caju merece destaque, já que movimenta todo um circuito produtivo na cidade e municípios circunvizinhos.

Segundo consta no Cadastro Central de Empresas, realizado pelo IBGE, no ano de 2015 o município contava com um número de 790 empresas atuantes, com um pessoal ocupado equivalente a 9.615 pessoas, sendo 8.771 delas trabalhadores assalariados, com uma remuneração estimada em 1,8 salários mínimos. Apesar dos números, a população 
A configuração territorial da cajucultura cearense: uma análise dos circuitos espaciais da produção e os círculos de cooperação da cajucultura no município de Pacajus
Kailton Jonatha Vasconcelos Rodrigues Denise Cristina Bomtempo

ocupada, no ano em questão, estava estimada em 14,0\% sendo que desse valor $42,9 \%$ possuíam rendimento nominal mensal per capita entre 1 e 2 salários mínimos.

Pacajus se encontra em uma das zonas industriais mais proeminentes do estado do Ceará. Junto do município vizinho, Horizonte, engendra um eixo que concentra uma grande quantidade de unidades fabris de segmentos distintos, tais como o têxtil, calçados, bebidas e alimentícios. Os dados do IPECE evidenciam essa característica, tal qual pode ser observada na tabela 1:

Tabela 1- Empresas industriais ativas - Pacajus - 2013-2015

\begin{tabular}{c|c|c}
$\mathbf{2 0 1 3}$ & $\mathbf{2 0 1 4}$ & $\mathbf{2 0 1 5}$ \\
\hline 312 & 322 & 475 \\
\hline
\end{tabular}

Fonte: Secretaria da Fazenda (SEFAZ), IPECE, 2015.

Org.: RODRIGUES, Kailton Jonatha Vasconcelos, 2017.

A quantidade expressiva de empresas instaladas no município está atrelada à consolidação de políticas públicas e iniciativas governamentais que tiveram início na década de 1970 na tentativa de estimular a industrialização do estado. Pacajus e Horizonte, em especial, compõem um corredor industrial em função da localização privilegiada, bem como aponta Pereira Junior (2002):

\begin{abstract}
A chegada da indústria em Horizonte e Pacajus se deve, por um lado, à presença abundante de mão-de-obra barata, aos benefícios fiscais e à intensa ação das lideranças políticas locais. No entanto, todos os fatores anteriores só se completam diante da estratégica posição geográfica do lugar, localizado num ponto de rápido e fácil acesso à capital metropolitana. Não é à toa que a BR-116 expressa um papel tão importante para a rede de fluxos que evidencia a relação do lugar com Fortaleza. Foi a presença desta rodovia que garantiu a Horizonte e Pacajus uma comunicação ativa com a metrópole, condicionando-os à instalação dos investimentos já citados. Toda essa importância está refletida no intenso tráfego de pessoas e produtos realizado diariamente neste trecho da BR. (PEREIRA JÚNIOR, 2002, p. 96).
\end{abstract}

Tais números revelam que a recente industrialização do município proporcionou o surgimento de uma massa de empregados que passaram a consumir e demandar os serviços disponibilizados na cidade. O comércio formal de Pacajus dá-se em torno do atacado e varejo ao longo das principais vias estruturantes do município, agregando redes lojistas de renome regional e nacional. Conforme o IPECE, este comércio conta com um 
A configuração territorial da cajucultura cearense: uma análise dos circuitos espaciais da produção e os círculos de cooperação da cajucultura no município de Pacajus

elevado número de estabelecimentos divididos por setor, como pode ser observado na Tabela 2.

Tabela 2 - Estabelecimentos comerciais, por setor - Pacajus - 2015

\begin{tabular}{c|c|c|c|c} 
Total & Atacadista & Varejista & $\begin{array}{c}\text { Reparação de veículos e } \\
\text { de objetos pessoais e } \\
\text { de uso doméstico }\end{array}$ \\
\hline 1.576 & 17 & 1.558 & \\
\hline
\end{tabular}

Fonte: Secretaria da Fazenda (SEFAZ), IPECE, 2015.

Org.: RODRIGUES, Kailton Jonatha Vasconcelos, 2017.

A dinâmica do comércio do município está alicerçada sobretudo pela presença do polo industrial instalado na fronteira com Horizonte. O fluxo de pessoas e materiais, proporcionados pela presença do polo, ao longo da faixa da BR - 116 que corta o município, é atrativo para a aplicação de capital na forma de projetos comerciais, que fomentam o surgimento de uma economia comercial formal pulsante, acompanhada de uma ainda maior economia informal. Além de uma série de serviços especializados para o atendimento de uma demanda dinâmica, moldada aos padrões de consumo das populações residentes.

Conforme o que foi apresentado, é possível afirmar que a indústria e o comércio possuem alto grau de relevância para a economia de Pacajus, todavia, a atividade agrícola coexiste juntamente com as atividades citadas. De acordo com as informações obtidas durante pesquisa empírica junto aos dirigentes da Secretaria de Agricultura do Município de Pacajus, é na agricultura que se apresenta um percentual significativo da renda no município, sobretudo daquela voltada para o cultivo do caju.

Em função do clima semiárido, característico dos municípios cearenses, a produção agrícola se resume as espécies adaptadas às condições necessárias para a manutenção delas no ambiente. Pacajus apresenta características edafoclimáticas propícias para a plantação de alguns gêneros arbóreos mais sofisticados, pois se encontra em uma área de Tabuleiro Litorâneo, que conforme aponta MORAIS (2006), apresenta solos:

[...] argissolos, profundos e moderadamente profundos, com textura variando de média (arenosa) a argilosa. Geralmente são bem drenados e porosos e com práticas corretivas possuem de médio a alto potencial agrícola. Na unidade dos tabuleiros é que se observa uma maior 
A configuração territorial da cajucultura cearense: uma análise dos circuitos espaciais da produção e os círculos de cooperação da cajucultura no município de Pacajus
Kailton Jonatha Vasconcelos Rodrigues Denise Cristina Bomtempo

diversificação vegetacional e florística. Dentre as espécies encontradas destaca-se o Pau-sangue (Pterocarpus violaceus) pelo porte arbóreo e arbustivo denso que exerce uma considerável proteção ao solo e o cajueiro (MORAIS, 2006, p. 138).

Tal composição de solo permite a existência de uma vegetação composta por uma caatinga arbustiva densa e um complexo vegetacional de zona litorânea, garantindo a possibilidade do cultivo de gêneros como banana, castanha de caju, coco da baía, goiaba, laranja, limão e manga. Esse potencial se expressa nas lavouras temporárias presentes no município, que apresentam um valor significativo para a economia, haja vista a extensão da área plantada e o valor obtido a partir da produção desses gêneros. As Tabelas 3 e 4, apresentam estes dados a partir de um material levantado pelo IPECE.

Tabela 3 - Pacajus - Lavouras temporárias - Área

\begin{tabular}{|c|c|c|c|c|c|c|}
\hline \multirow{4}{*}{$\begin{array}{l}\text { Estado } \\
\text { Município }\end{array}$} & \multicolumn{6}{|c|}{ Lavouras temporárias } \\
\hline & \multicolumn{6}{|c|}{ Área (ha) } \\
\hline & \multicolumn{3}{|c|}{ Destinada à produção - colheita } & \multicolumn{3}{|c|}{ Colhida } \\
\hline & 2013 & 2014 & 2015 & 2013 & 2014 & 2015 \\
\hline & \multicolumn{6}{|c|}{ Banana } \\
\hline Ceará & 49.255 & 46.654 & 44.482 & 49.255 & 46.654 & 44.482 \\
\hline \multirow[t]{2}{*}{ Pacajus } & 13 & 7 & 7 & 13 & 7 & 7 \\
\hline & \multicolumn{6}{|c|}{ Castanha de caju } \\
\hline Ceará & 405.466 & 378.146 & 389.358 & 405.458 & 378.094 & 374.426 \\
\hline \multirow[t]{2}{*}{ Pacajus } & 10.275 & 10.275 & 9.633 & 10.275 & 10.275 & 9.633 \\
\hline & \multicolumn{6}{|c|}{ Coco-da-baía } \\
\hline Ceará & 44.024 & 42.168 & 38.099 & 44.024 & 42.168 & 38.099 \\
\hline \multirow{2}{*}{ Pacajus } & 156 & 62 & 62 & 156 & 62 & 62 \\
\hline & \multicolumn{6}{|c|}{ Goiaba } \\
\hline Ceará & 1.197 & 1.519 & 1.438 & 1.197 & 1.515 & 1.438 \\
\hline \multirow[t]{2}{*}{ Pacajus } & 3 & 3 & 80 & 3 & 3 & 80 \\
\hline & \multicolumn{6}{|c|}{ Laranja } \\
\hline Ceará & 1.965 & 1.812 & 1.609 & 1.965 & 1.789 & 1.586 \\
\hline \multirow[t]{2}{*}{ Pacajus } & 3 & 3 & 3 & 3 & 3 & 3 \\
\hline & \multicolumn{6}{|c|}{ Limão } \\
\hline Ceará & 1.282 & 1.310 & 1.123 & 1.282 & 1.310 & 1.123 \\
\hline \multirow[t]{2}{*}{ Pacajus } & 2 & 2 & 2 & 2 & 2 & 2 \\
\hline & \multicolumn{6}{|c|}{ Manga } \\
\hline Ceará & 5.576 & 5.559 & 5.662 & 5.576 & 5.559 & 5.662 \\
\hline Pacajus & 18 & 18 & 18 & 18 & 18 & 18 \\
\hline
\end{tabular}


A configuração territorial da cajucultura cearense: uma análise dos circuitos espaciais da produção e os círculos de cooperação da cajucultura no município de Pacajus
Kailton Jonatha Vasconcelos Rodrigues Denise Cristina Bomtempo

Tabela 4 - Pacajus - Lavouras temporárias - Produção

\begin{tabular}{|c|c|c|c|c|c|c|}
\hline \multirow{4}{*}{$\begin{array}{c}\text { Estado } \\
\text { Município }\end{array}$} & \multicolumn{6}{|c|}{ Lavouras temporárias } \\
\hline & \multicolumn{6}{|c|}{ Produção } \\
\hline & \multicolumn{3}{|c|}{ Quantidade (t) } & \multicolumn{3}{|c|}{ Valor (R\$ mil) } \\
\hline & 2013 & 2014 & 2015 & 2013 & 2014 & 2015 \\
\hline & \multicolumn{6}{|c|}{ Banana } \\
\hline Ceará & 375.531 & 452.541 & 385.028 & 301.883 & 352.141 & 327.684 \\
\hline \multirow[t]{2}{*}{ Pacajus } & 23 & 27 & 39 & 21 & 22 & 41 \\
\hline & \multicolumn{6}{|c|}{ Castanha de caju } \\
\hline Ceará & 53.112 & 51.211 & 52.118 & 89.458 & 108.286 & 171.708 \\
\hline \multirow[t]{2}{*}{ Pacajus } & 2.545 & 3.762 & 2.777 & 4.969 & 8.694 & 9.891 \\
\hline & \multicolumn{6}{|c|}{ Coco-da-baía } \\
\hline Ceará & 206.071 & 246.959 & 189.398 & 111.610 & 136.834 & 116.446 \\
\hline \multirow[t]{2}{*}{ Pacajus } & 362 & 74 & 291 & 191 & 51 & 144 \\
\hline & \multicolumn{6}{|c|}{ Goiaba } \\
\hline Ceará & 13.984 & 18.936 & 14.005 & 13.393 & 21.655 & 18.008 \\
\hline \multirow{2}{*}{ Pacajus } & 3 & 12 & 548 & 2 & 17 & 603 \\
\hline & \multicolumn{6}{|c|}{ Laranja } \\
\hline Ceará & 13.556 & 12.684 & 9.915 & 7.445 & 7.024 & 5.994 \\
\hline \multirow[t]{2}{*}{ Pacajus } & 4 & 12 & 18 & 2 & 9 & 14 \\
\hline & \multicolumn{6}{|c|}{ Limão } \\
\hline Ceará & 8.736 & 8.934 & 6.609 & 5.893 & 6.535 & 5.489 \\
\hline \multirow[t]{2}{*}{ Pacajus } & 3 & 6 & 9 & 1 & 5 & 9 \\
\hline & \multicolumn{6}{|c|}{ Manga } \\
\hline Ceará & 46.632 & 49.305 & 45.259 & 23.413 & 30.788 & 30.513 \\
\hline Pacajus & 50 & 99 & 129 & 40 & 69 & 84 \\
\hline
\end{tabular}

Fonte: Secretaria da Fazenda (SEFAZ), IPECE, 2015.

Org.: RODRIGUES, Kailton Jonatha Vasconcelos, 2017.

Destaque para a produção de castanha de caju, que apresenta os números mais elevados dentro das lavouras temporárias do município, tanto a nível de área plantada quanto a quantidade produzida. A produção com 2.777 toneladas de castanha de caju produzidas em 2015 , rendeu cerca de $\mathrm{R} \$ 9.891,00$ pago ao produtor por quantidade e preço médio corrente. Deste modo, fica evidente a relevância econômica dessa produção em Pacajus, o que é ainda mais explicitado quando se observa o Gráfico 1, contendo um histórico produtivo dentro de um período de treze anos. 
A configuração territorial da cajucultura cearense: uma análise dos circuitos espaciais da produção e os círculos de cooperação da cajucultura no município de Pacajus
Kailton Jonatha Vasconcelos Rodrigues Denise Cristina Bomtempo

Gráfico 1 - Pacajus -Castanha de caju / Área colhida (Unidade: ha)

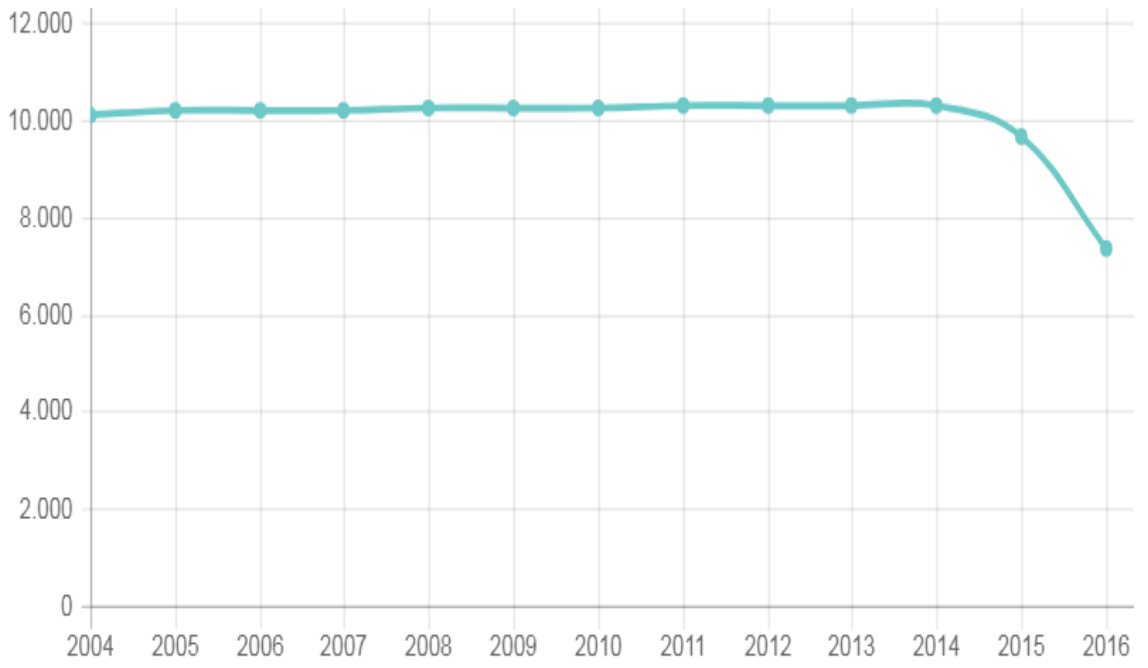

Fonte: Levantamento Sistemático da Produção Agrícola - LSPA, 2017.

Org.: RODRIGUES, Kailton Jonatha Vasconcelos, 2017.

A variação da área colhida do município é relativamente constante, oscilando a medida em que a produção do estado é alterada, o que reflete uma constância geral da produção estadual e nacional, no entanto, é perceptível um declínio acentuado no decorrer dos últimos anos. Tal situação dá-se sobretudo pelo desinteresse do poder público unido a uma má gestão destas áreas, o que foi agravada pelo longo "[...] período de seca que assolou a região entre 2012 e 2016" e também pela "ocorrência de pragas e doenças, que causaram não somente quebra de safras, mas também a morte de grande número de plantas, principalmente as mais antigas" VIDAL (2017, p.19). Esse contexto é a realidade da maioria dos municípios produtores, inclusive, em muitas regiões os produtores cortam os cajueiros mortos e comercializaram a madeira, atividade que é bastante presente no cotidiano de Pacajus, onde a retirada dos velhos cajueirais é perceptível ao longo da BR116 e nas áreas recém urbanizadas (Figura 1), em que é possível perceber um novo loteamento onde antes havia um cajueiral, ao longe é possível perceber a presença de cajueiros nos lotes ainda não construídos. 
A configuração territorial da cajucultura cearense: uma análise dos circuitos espaciais da produção e os círculos de cooperação da cajucultura no município de Pacajus
Kailton Jonatha Vasconcelos Rodrigues Denise Cristina Bomtempo

Figura 1 - Loteamento em Pacajus as margens da BR -116 com a presença de cajueiros ao fundo

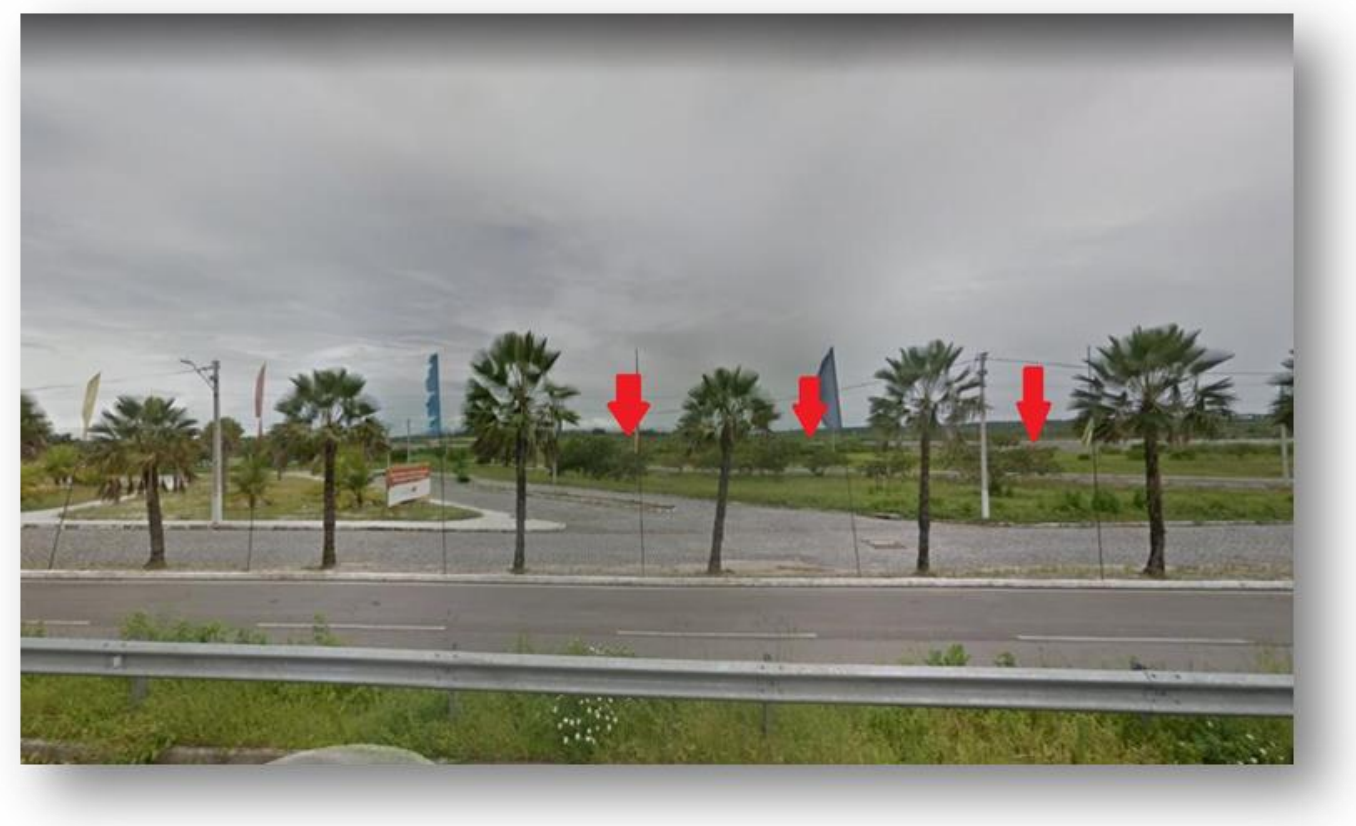

Fonte: RODRIGUES, Kailton Jonatha Vasconcelos, 2017.

No que se refere à quantidade produzida, a cajucultura no município apresenta um comportamento cíclico, pois, nos anos de 2010, 2012 e 2013, a produção foi menor do que a registrada em 2006. Esse tipo de comportamento da produção aparenta estar diretamente associada aos dados pluviométricos ocorridos na quadra chuvosa dos anos em questão; todavia, “[...] a idade das plantas e o material genético (tipo de cajueiro) certamente estão envolvidos com o grau de sensibilidade ao estresse hídrico" (SERRANO, PESSOA, 2016, p. 46). Entretanto, em alguns desses anos, as precipitações apresentaram variação consideradas mais satisfatórias (Gráfico 2), nos anos de 2008, 2011 e 2014, períodos que propiciaram produções acima de 3 mil toneladas, o inverso foi verificado nos anos de baixa precipitação, 2010 ,2012, 2015 e 2016, o que reforça a relação desta produção com o contexto da estiagem. 
A configuração territorial da cajucultura cearense: uma análise dos circuitos espaciais da produção e os círculos de cooperação da cajucultura no município de Pacajus
Kailton Jonatha Vasconcelos Rodrigues Denise Cristina Bomtempo

Gráfico 2 - Pacajus - Castanha de caju/ Quantidade produzida (Unidade: t)

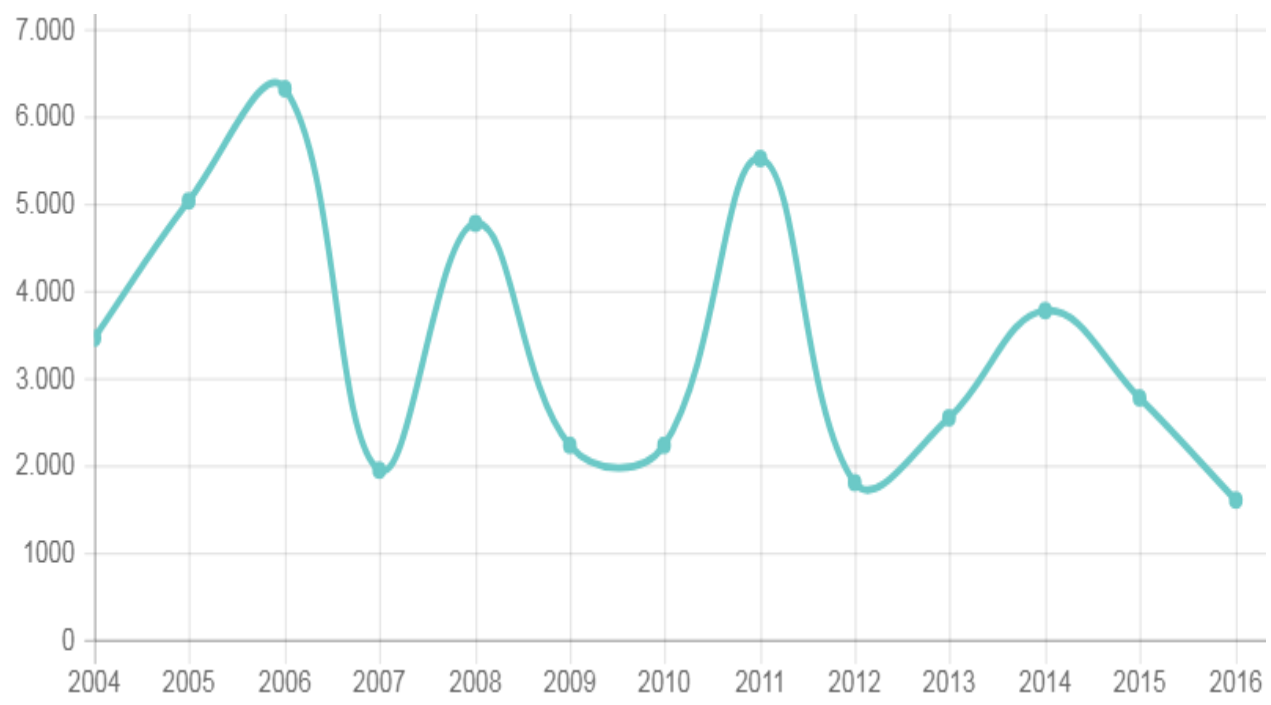

Fonte: Levantamento Sistemático da Produção Agrícola - LSPA, 2017.

Org.: RODRIGUES, Kailton Jonatha Vasconcelos, 2017.

É também importante reconhecer a relevância do valor da produção, que consiste na quantidade e preço médio corrente pago ao produtor de acordo com os períodos de colheita e comercialização de cada produto, uma porção significativa para a manutenção do setor produtivo. Em Pacajus, esse valor oscila conforme as variáveis anteriores, dependendo do resultado da colheita do ano em questão, além de fatores externos, tais quais a demanda pela castanha e a flutuação do seu preço nacional e internacionalmente. O valor de produção ao longo de treze anos (2004-2016), possui alterações bem significativas (Gráfico 3), tendo seu pico em 2015, em função do preço da castanha elevado por sua escassez no mercado, e o seu ponto mais rebaixado em 2007 ano com uma quantidade razoável desse produto no mercado. 
A configuração territorial da cajucultura cearense: uma análise dos circuitos espaciais da produção e os círculos de cooperação da cajucultura no município de Pacajus
Kailton Jonatha Vasconcelos Rodrigues Denise Cristina Bomtempo

Gráfico 3 - Pacajus - Castanha de caju / Valor da produção (Unidade: R \$ x1000)

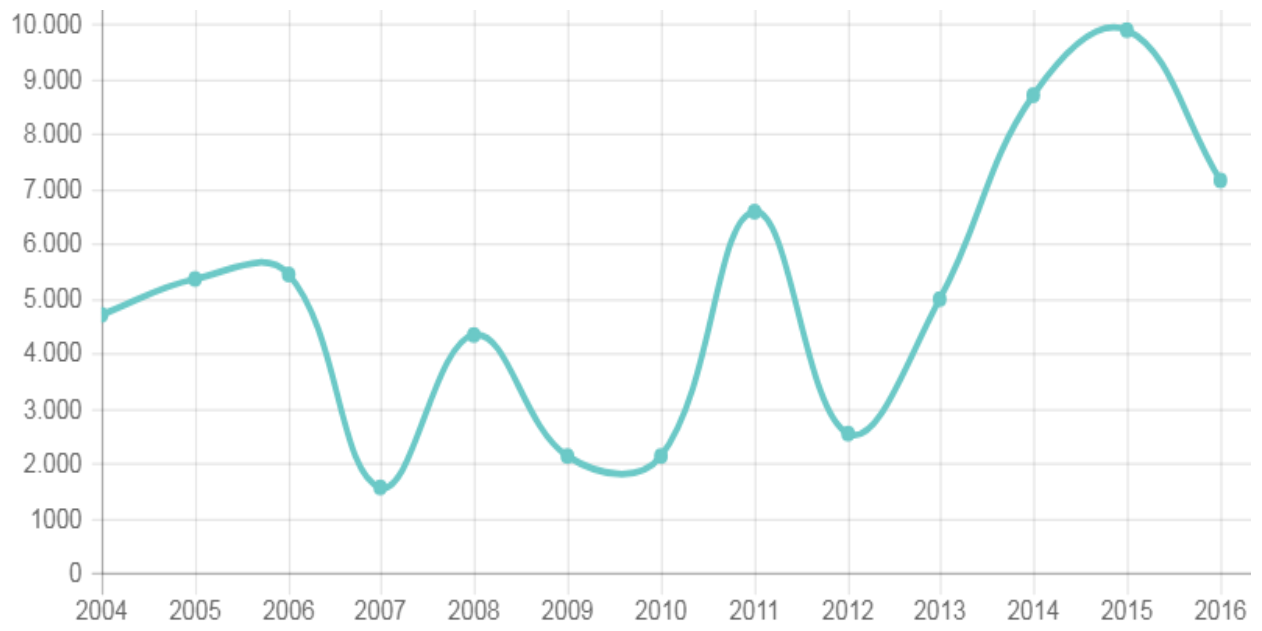

Fonte: Levantamento Sistemático da Produção Agrícola - LSPA, 2017.

Org.: RODRIGUES, Kailton Jonatha Vasconcelos, 2017.

Ademais, esses dados estabelecem o precedente para o entendimento de Pacajus enquanto uma das áreas de relevância dentro da cajucultura do estado, uma vez que apresenta características que o distingue da maioria dos municípios atrelados a essa cultura. No entanto, os dados por si só não retificariam essa conclusão, carecendo de uma análise acerca do histórico do município e seu envolvimento para com o processo de consolidação da cajucultura no estado do Ceará.

Não é por acaso que Pacajus lidera e dá nome a um dos polos da cajucultura do estado do Ceará. Seu vínculo com a produção está associado ao seu passado como lugar adequado para a implantação de um novo segmento do setor. Atualmente, de acordo com a ADECE (2009), o município concentra um dos polos mais proeminentes do cultivo do caju, polo esse que agrega os municípios vizinhos, Chorozinho, Horizonte, Cascavel, Pindoretama, Barreira, Aquiraz, Caucaia, Aracoiaba e Ocara, todos estes com estreitos laços com a cajucultura.

\section{Configuração territorial e mudanças técnicas: a cajucultura cearense e o papel de Pacajus}

A própria delimitação dos limites de Pacajus alude a uma área produtiva significativa para cajucultura, uma vez que já abrangeu dois dos municípios que hoje compõem seu polo produtivo, Chorozinho e Horizonte, ambos desmembrados de Pacajus 
A configuração territorial da cajucultura cearense: uma análise dos circuitos espaciais da produção e os círculos de cooperação da cajucultura no município de Pacajus
Kailton Jonatha Vasconcelos Rodrigues Denise Cristina Bomtempo

em 1987, retificados pelas leis estaduais n. ${ }^{\circ} 11.305$, de 13-03-1987, e n. ${ }^{\circ} 11.321$, de 2205-1987, elevando os dois antigos distritos a categoria de município.

O extenso território unido às condições edafoclimáticas favoráveis ao plantio do cajueiro possibilitou o surgimento de uma produção significativa que atendia a demanda regional, mas se restringia a estas escalas uma vez que o interesse pelos grandes mercados ainda não havia atraído os investidores do setor. Tal conjuntura é alterada quando em 1941, o industrial do setor têxtil, Pedro Philomeno Ferreira Gomes, financia a plantação inicial de 200.000 pés de caju, em Pacajus, no que ele denominou que seria a fazenda Guarany, tonando-se pioneiro do cultivo racional de cajueiros no Brasil (GOMES, 1988).

Tal iniciativa surgiu no intuito de garantir o plantio dos cajueirais para a eventual instalação das indústrias processadoras que se seguiria a partir das políticas públicas posteriores. Como afirma Leite (1998), o empreendimento:

[...] teve o objetivo de incrementar o beneficiamento e a comercialização de alguns produtos originários dessa cultura na Fazenda Guarany, localizada às margens da BR-116 (liga Fortaleza ao Sul do país), utilizando-se da estrutura de hotel e restaurante, de propriedade do referido empresário, que serviam de apoio ao ponto de ônibus interestadual que funcionava naquela localidade. Esse feito parecia apontar boas perspectivas para o futuro da agroindústria, uma vez que ali estavam sendo gestadas novas formas de elevar e controlar a oferta de matéria-prima, bem como de uma maior diversificação nos usos dos produtos do cajueiro, uma vez que não se tratava apenas de aproveitar a castanha, mas também o pseudofruto (na forma de doces, sucos, cajuína etc), em um projeto integrado. (LEITE, 1998, p. 22).

Nesse sentido, os grandes plantios sistematizados de cajueiro, voltados para fins mercadológicos, datam do final da década de 1950 e começo da década de 1960. Haja vista a iniciativa de Philomeno Gomes no município de Pacajus, no Ceará, cuja propriedade, fazenda Guarany, seria então precursora do que viria se tornar a política pública dos anos seguintes, uma espécie de experiência de reflorestamento assentada na ideia de uma futura área produtiva para assegurar a matéria-prima da indústria do caju e o aproveitamento integral de seus derivados. Tanto que em 1957, foi promulgada a campanha "Um milhão de cajueiros para o Ceará", do governo do Ceará, através da lei no 3.544, que auxiliaria financeiramente os produtores que plantassem os cajueiros. 
A configuração territorial da cajucultura cearense: uma análise dos circuitos espaciais da produção e os círculos de cooperação da cajucultura no município de Pacajus
Kailton Jonatha Vasconcelos Rodrigues Denise Cristina Bomtempo

Ao passo que essa medida alcançou seus objetivos primordiais, a Fazenda Guarany alterou em julho de 1962, sua razão social para Caju do Brasil S.A. Agroindustrial Cajubraz, atuando na época como uma das primeiras empresas beneficiadoras de castanha de caju do estado do Ceará. Atualmente, a empresa tem seu enfoque na fabricação de sucos concentrados e não concentrados de frutas, hortaliças e legumes e divide espaço com outra empresa do gênero, Sucos do Brasil S/A, cujo o nome fantasia é Jandaia, uma das mais proeminentes empresas do ramo de sucos no Brasil.

Em seu site a Jandaia informa que “[...] o caju é plantado na própria fazenda, sendo responsável por inúmeros empregos diretos e indiretos em toda a sua cadeia produtiva". Acrescenta que "[...] é também responsável pela geração de diversos empregos diretos e indiretos através da compra da matéria-prima de pequenas propriedades agrícolas, sempre próximas ao local de produção dos sucos, além dos vários representantes e distribuidores espalhados por todo o Brasil é responsável ainda pela geração de outros 5 mil empregos indiretos, através das compras da matéria-prima de pequenas propriedades agrícolas".

A presença desta empresa em Pacajus até os dias atuais revela o intrínseco envolvimento do município para com os interesses dos industriais da cajucultura, evidenciando as relações mantidas entre o aparelho institucional através das políticas agrícolas e os interesses do capital.

Tal característica é fruto de mudanças de ordem técnica, política e de regulamentação, fatores esses que rearranjaram o alcance e a complexidade dos circuitos espaciais produtivos e de seus respectivos círculos de cooperação, uma vez que o advento e difusão das tecnologias da informação e da comunicação proporcionaram o aumento das trocas em escala mundial. A cajucultura, portanto, passaria a incorporar essa transição, o que possibilitou a incorporação de novos elementos dentro de sua lógica. Como foi visto anteriormente, essas alterações foram impulsionadas na década de 1970, mas tiveram início ainda mais cedo, com uma tênue aplicação de recursos em pesquisas que viriam a tomar proporções mais abrangentes em um futuro próximo.

Um dos exemplos desses investimentos foi a instalação do Campo Experimental de Pacajus, fundado em 1955, possuindo uma área de 202 hectares. O complexo teve como principal atividade a pesquisa com caju e tecnologia de frutas, a partir de uma coleção de matrizes de cajueiro, que seria objeto de investigação agronômica da instituição, sob a jurisdição do antigo IPEANE (Instituto de Pesquisa e Experimentação 
A configuração territorial da cajucultura cearense: uma análise dos circuitos espaciais da produção e os círculos de cooperação da cajucultura no município de Pacajus
Kailton Jonatha Vasconcelos Rodrigues Denise Cristina Bomtempo

Agropecuária do Nordeste), subordinado ao DNPEA (Departamento Nacional de Pesquisa Agropecuária), do Ministério da Agricultura. Tal política promoveu um longo processo de pesquisas científicas que conseguiram compreender elementos de grande importância para a botânica e o melhoramento genético da cultura.

Foi na década de 1970, mais precisamente a partir de 1974, que o Campo Experimental passou a integrar o sistema Embrapa, através da criação da Unidade de Pesquisa de Âmbito Estadual de Pacajus (UEPAE de Pacajus), cedido à EPACE (Empresa de Pesquisa Agropecuária do Ceará). Após a criação do Centro Nacional de Pesquisa do Caju, em 1987, o Campo Experimental de Pacajus retorna à Embrapa e integra o que viria a se tornar a EMBRAPA Agroindústria de Frutas Tropicais.

Os impactos resultantes do investimento nessas pesquisas incrementaram a produtividade das espécies de cajueiros subsequentes, através da utilização de plantas com caracteres genéticos de boa produtividade e da aplicação de tratos culturais adequados à cultura. Processo que culminou na criação do cajueiro anão precoce, cruzamento de várias espécies dotadas de propriedades que as tornavam mais aptas ao plantio, cujas caraterísticas apresentavam, “[...] quando adulta, um porte menor em relação aos cajueiros-comuns, o que favorecia a aplicação de tratos culturais, o adensamento e a colheita manual do pedúnculo" (SERRANO; OLIVEIRA, 2016, p.147).

Esse avanço técnico-científico característico do período da globalização, possibilitou uma perspectiva mais favorável aos pequenos e médios produtores, uma vez que:

Devido ao porte baixo dos clones de cajueiros, o que facilitou a prática da colheita manual de cajus de qualidade, o pedúnculo de caju, que até então não era aproveitado, passou a ser comercializado tanto in natura quanto pelas indústrias processadoras de sucos (CRISÓSTOMO et al., 2002). Ademais, com os avanços, o caju passou a ser transportado para mercados distantes mais de $4.000 \mathrm{~km}$ do local de origem (PAIVA et al., 1998a). Com a industrialização do pedúnculo (sucos, doces, compotas, geleias e outros), criou-se uma alternativa para a agregação de valor e geração de renda para os cajucultores do Nordeste do Brasil (PAIVA, 2010) e (SERRANO, LEITE, 2013, p.78).

No entanto, a aplicação de novas técnicas e distribuição dos clones tem sido pouco efetiva, uma vez que o acesso a essas ferramentas é dificultado pela ausência de capacitação dos pequenos produtores; assistência técnica insuficiente para atender a 
A configuração territorial da cajucultura cearense: uma análise dos circuitos espaciais da produção e os círculos de cooperação da cajucultura no município de Pacajus
Kailton Jonatha Vasconcelos Rodrigues Denise Cristina Bomtempo

demanda dos municípios; políticas públicas ineficazes e a estiagem que afetou a produção ao longo dos últimos anos.

Embora os problemas supracitados sejam alguns dos principais desafios da cajucultura modernizada, o desenvolvimento dessas tecnologias alterou o cenário do setor mundialmente, “[...] tendo inspirado a aplicação de práticas semelhantes entre os maiores países produtores, que iniciaram seus próprios programas e passam a desenvolver tecnologias capazes de moldar os cajueiros aos mais diferentes tipos de solos e climas", como afirma Antônio Calixto Lima, pesquisador da Embrapa Agroindústria Tropical em entrevista realizada em Março de 2017.

É interessante perceber que os processos que modificam a forma como a cajucultura se manifesta no espaço, ocorrem a medida em que a dinâmica da produção se torna cada vez mais fluida e dispersa, grande parte em virtude dos adventos tecnológicos e os avanços de cunho científico. O tempo se comprimiu e as diferentes escalas estão cada vez mais articuladas, possibilitando que uma cultura tradicional ganhe outra conformação quando inserida numa economia globalizada, sem que, no entanto, perca sua especificidade, pois se as práticas podem ser alteradas para atender a demanda do mercado, estas estarão fortemente vinculadas às relações mantidas no espaço em que se realizam. Destarte, esse fenômeno complementará as relações verticais num movimento dialético que promove características singulares as práticas exercidas no lugar, e por ventura no território.

Dentro desse contexto, o município de Pacajus apresenta elementos que o distingue como um dos pontos mais relevantes na confluência dos fluxos materiais e imateriais que integram a cajucultura cearense, visto que é possível identificar o encadeamento das relações mantidas entre os agentes em função desses fluxos dentro do território, tornando evidente o papel do município em relação à divisão territorial do trabalho, quando Pacajus exerce determinada centralidade em uma escala regional mas ainda está submetida aos agentes corporativos que sistematizam o setor a partir da cidade de Fortaleza. Tais agentes atuam no sentido de conectar as diversas etapas, espacialmente separadas, da produção, articulando os diversos agentes e lugares que compõem o circuito espacial de produção (CASTILLO e FREDERICO, 2010, p. 464).

Essa configuração pode ser melhor compreendida quando se investiga precisamente a atuação dos agentes em lócus (tanto para a cajucultura que se apresenta 
A configuração territorial da cajucultura cearense: uma análise dos circuitos espaciais da produção e os círculos de cooperação da cajucultura no município de Pacajus
Kailton Jonatha Vasconcelos Rodrigues Denise Cristina Bomtempo

com uma estrutura moderna, como para aquela que ainda se organiza a partir de relações, elementos e práticas tradicionais), para que se possa constatar como estes alteram, estruturam e dinamizam as relações mantidas entre as etapas que compõem o processo produtivo atrelado ao caju e seus derivados.

\section{Os elementos da cajucultura em Pacajus: coexistências}

É deveras marcante a presença do caju e de seus componentes na vida do pequeno agricultor, seja na alimentação da família ou dos animais de criação; na queima da lenha retirada do cajueiro; na possibilidade de sombra proporcionada pela extensa copa; no consumo do suco e da cajuína, ou sua eventual comercialização; ou pela renda adquirida por meio da venda da castanha; até mesmo nas experiências de cunho sentimental, exacerbadas pelo vínculo mantido entre o agricultor e sua propriedade. A característica predominante dessa cajucultura familiar é a maior presença de trabalhadores da própria família, o que proporciona um rendimento que na maioria das vezes dispensa desembolsos com pagamento de salários. Em se tratando desse tipo de agricultura, a finalidade é potencializar o rendimento do trabalho.

Embora esta relação ocorra de maneira corriqueira, o cultivo do caju usualmente é praticado de modo tradicional, aquém aos métodos mais avançados existentes, de modo que se baseia no tempo da produção natural da planta, o que implica na pouca interferência humana ao longo do tempo de maturação dos frutos. Apesar dessa configuração, é possível, também, identificar coexistências, ou seja, produtores que se dedicam parcialmente ou inteiramente a esta atividade, estabelecendo um manejo mais adequado aos preceitos técnicos dos cajueirais e consequentemente a garantia de uma safra ideal para o desdobrar da cajucultura.

No que diz respeito às práticas convencionais, cujo cerne está contido na prática ocasional da produção de caju em pequenas propriedades rurais, a atividade ocorre de modo espontâneo, onde no período do ano que corresponde à fase de maturação dos frutos as famílias se dedicam exclusivamente à colheita das culturas tradicionais enquanto que na entressafra, em período posterior, recolhem do chão o caju caído para a separação da polpa e da castanha, que, por sua vez, possuem destinações diferenciadas. Enquanto a polpa intacta é consumida no próprio lar ou comercializada na feira, a polpa inapropriada 
A configuração territorial da cajucultura cearense: uma análise dos circuitos espaciais da produção e os círculos de cooperação da cajucultura no município de Pacajus
Kailton Jonatha Vasconcelos Rodrigues Denise Cristina Bomtempo

é direcionada à ração animal. No que concerne à castanha, é tanto consumida na propriedade, como também armazenada para posterior negociação com os corretores de castanha.

Via de regra, os estabelecimentos possuem poucos investimentos e quase não utilizam insumos modernos. Com propriedades rurais organizadas de maneira concentrada e de baixo nível tecnológico aplicado, é possível explicar em parte o enfraquecimento que acomete esta produção. Assim, nas pequenas propriedades ocorrem uma parca ou quase ausência de aplicação tecnológica, formando circuitos espaciais da produção em que os fluxos territoriais, bem como a escala de relações e distribuição do próprio caju e dos seus subprodutos tenham articulações diversas e ao mesmo tempo múltiplas.

A distribuição e comercialização do pedúnculo, por exemplo, é realizada de maneira mais direta e por isso, são absorvidos pela escala local e regional. Em relação à castanha de caju, essa configuração escalar se difere, pois, a comercialização da castanha ocorre a partir de Pacajus, mas ganha dimensão multiescalar, ou seja, atende tanto ao mercado local, regional, como também às demandas de empresas que realizam suas transações econômicas na escala nacional e global.

\section{Os circuitos espaciais da produção atrelados ao pedúnculo do caju}

Há bastante tempo os conceitos de circuito espacial produtivo e círculos de cooperação vêm sendo trabalhados por vários geógrafos para a compreensão dos mais diversos setores produtivos. Para Santos (1986) ${ }^{1}$,

[...] os circuitos espaciais nos dão a situação relativa dos lugares, isto é, a definição, num dado momento, da respectiva fração de espaço em função da divisão do trabalho sobre o espaço total de um país. Aí se conjugam as relações de produção social, que os circuitos de ramos tipificam, as relações sociais de produção, dadas pelas firmas, mas também as relações de produção do passado, mantidas ou rejuvenescidas pelas relações atuais e representadas por relíquias ou heranças, tanto na paisagem quanto na própria estruturação social. (p. 130).

Ainda, de acordo com Santos e Silveira (2001), os "[...] circuitos espaciais de produção e círculos de cooperação mostram o uso diferenciado de cada território por parte das empresas, das instituições, dos indivíduos e permitem compreender a hierarquia dos 
A configuração territorial da cajucultura cearense: uma análise dos circuitos espaciais da produção e os círculos de cooperação da cajucultura no município de Pacajus
Kailton Jonatha Vasconcelos Rodrigues Denise Cristina Bomtempo

lugares desde a escala regional até a escala mundial" (p. 144).Os círculos de cooperação evidenciam a conexão das diversas etapas, espacialmente separadas, da produção, articulando os diversos agentes e lugares que compõem o circuito espacial de produção (CASTILLO e FREDERICO, 2010, p. 464). Tais entendimentos têm apontado a relevância e eventualmente a instrumentalização desses conceitos no sentido de possibilitar o reconhecimento dos fluxos materiais e imateriais, em outras palavras, identificar como as diferentes etapas produtivas se manifestam no espaço, e as relações de cooperação e competição estabelecidas entre os múltiplos agentes que atuam no circuito.

A partir de tais reflexões, almejamos contribuir para o entendimento da totalidade das atividades produtivas que define distintas dinâmicas territoriais, o que possibilita, em tese, a percepção das relações manifestadas no território. Para tanto, este texto apresenta uma série de tópicos que articula o referencial com a validação empírica, na qual aborda as características da produção, partindo de um panorama do cultivo tradicional do caju, evidenciando as práticas culturais e as características simbólicas atreladas a esta, até culminar no entendimento da cajucultura moderna, suas ramificações, pretensões e estruturação no território cearense, mais precisamente em Pacajus.

Quando se trata de compreender as partes do caju, é possível afirmar que a parte macia e espessa, o pseudofruto do cajueiro, é uma fonte riquíssima em vitamina $\mathrm{C}$ e tem inúmeros usos, todavia possui pouco ou nenhum valor no mercado externo, mas é muito apreciada no Brasil. Durante a colheita (de agosto a novembro) os produtores recolhem as frutas com a melhor aparência e as separam em caixotes para organizar e contabilizar a quantidade produzida (Figura 2). Geralmente esse trabalho não ocorre de maneira a assegurar a qualidade do pedúnculo, uma vez que a castanha, na grande maioria das vezes, é o enfoque desses pequenos e médios agricultores. Uma vez colhido o caju, a castanha é separada do pedúnculo e a partir daí ambos têm destinações diferentes. 
A configuração territorial da cajucultura cearense: uma análise dos circuitos espaciais da produção e os círculos de cooperação da cajucultura no município de Pacajus
Kailton Jonatha Vasconcelos Rodrigues Denise Cristina Bomtempo

Ilustração 2 - Armazenamento do caju após a colheita

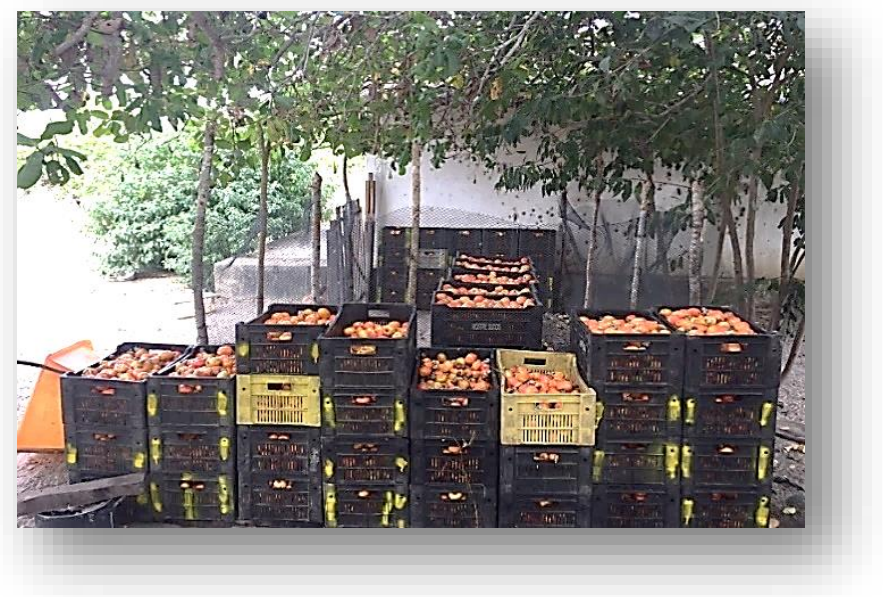

Fonte: SILVA, Elder Batista da, 2017.

Bastante utilizado na culinária regional, o pedúnculo se faz presente em uma diversidade de pratos populares tão variantes quanto às localidades em que são consumidos. Em face disso, é comum que sejam colhidos ainda na árvore. A fruta fresca é utilizada tanto para consumo próprio quanto para a comercialização em feira e mercados (Figura 3).

Ilustração 3 - Caju fresco comercializado na feira de Pacajus

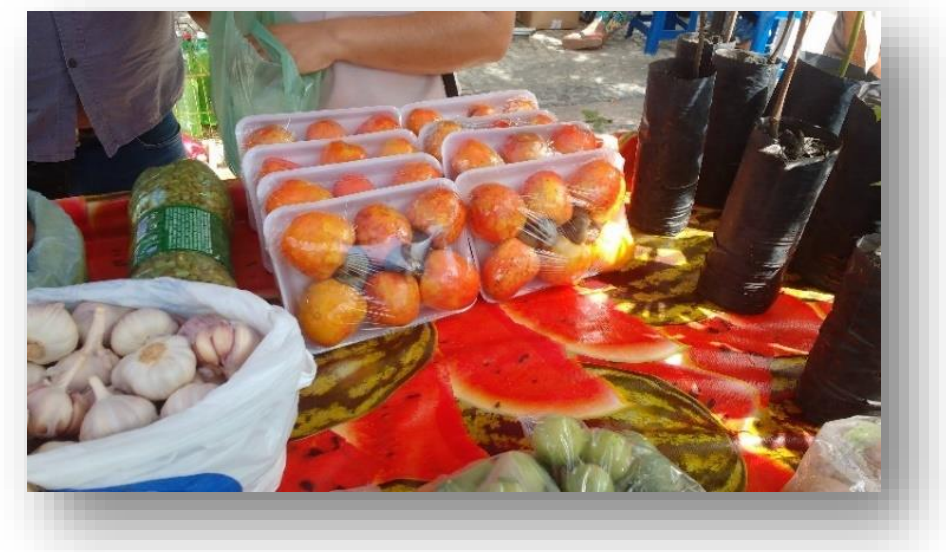

Fonte: Pesquisa empírica realizada nos meses de outubro - novembro, 2017.

Org.: RODRIGUES, Kailton Jonatha Vasconcelos, 2017.

Na forma de bebida, como geralmente é consumido, o pedúnculo serve de matériaprima para sucos, refrescos e "vitaminas", quando se adiciona água ou leite. A principal bebida advinda da fruta consiste no suco integral do caju, que é um líquido com alto teor 
A configuração territorial da cajucultura cearense: uma análise dos circuitos espaciais da produção e os círculos de cooperação da cajucultura no município de Pacajus
Kailton Jonatha Vasconcelos Rodrigues Denise Cristina Bomtempo

de polpa, extraído do caju mediante processamento tecnológico adequado, não gaseificado, não fermentado, de cor, sabor e aroma característicos, submetido a tratamento térmico, que assegura a sua apresentação e conservação até o momento do consumo. A tradicional cajuína (Figura 4), é o suco filtrado, engarrafado e cozido e é um elemento bastante presente no cotidiano das populações tradicionais, havendo uma quantidade significativa de fabricação desta bebida de maneira artesanal de modo que é recorrente a presença delas em feiras e mercados regionais, até mesmo nas redes de supermercados.

Ilustração 4 - Cajuína caseira comercializado na feira de Pacajus

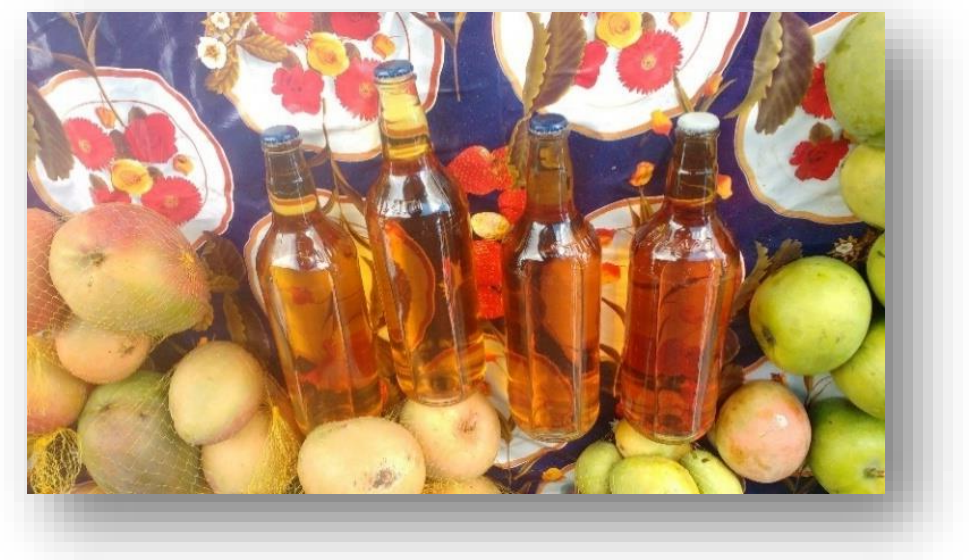

Fonte: Pesquisa empírica realizada nos meses de outubro - novembro, 2017.

Org.: RODRIGUES, Kailton Jonatha Vasconcelos, 2017.

Há também a polpa da fruta, que é processada e embalada para ser consumida em sucos, sorvetes, doces e bebidas, largamente produzida e comercializada por pequenas e médias empresas do ramo de bebidas. O mel de caju, também conhecido como melado de caju que é um produto do suco clarificado de caju, de cor âmbar claro e odor característico é comercializado em feiras como uma bebida medicinal. Além do mocororó, aguardente de origem indígena, que consiste no suco fermentado, cru ou cozido, de alto teor alcoólico (Figura 5). 
A configuração territorial da cajucultura cearense: uma análise dos circuitos espaciais da produção e os círculos de cooperação da cajucultura no município de Pacajus
Kailton Jonatha Vasconcelos Rodrigues Denise Cristina Bomtempo

Ilustração 5 - Mocororó, polpa do caju e mel do caju
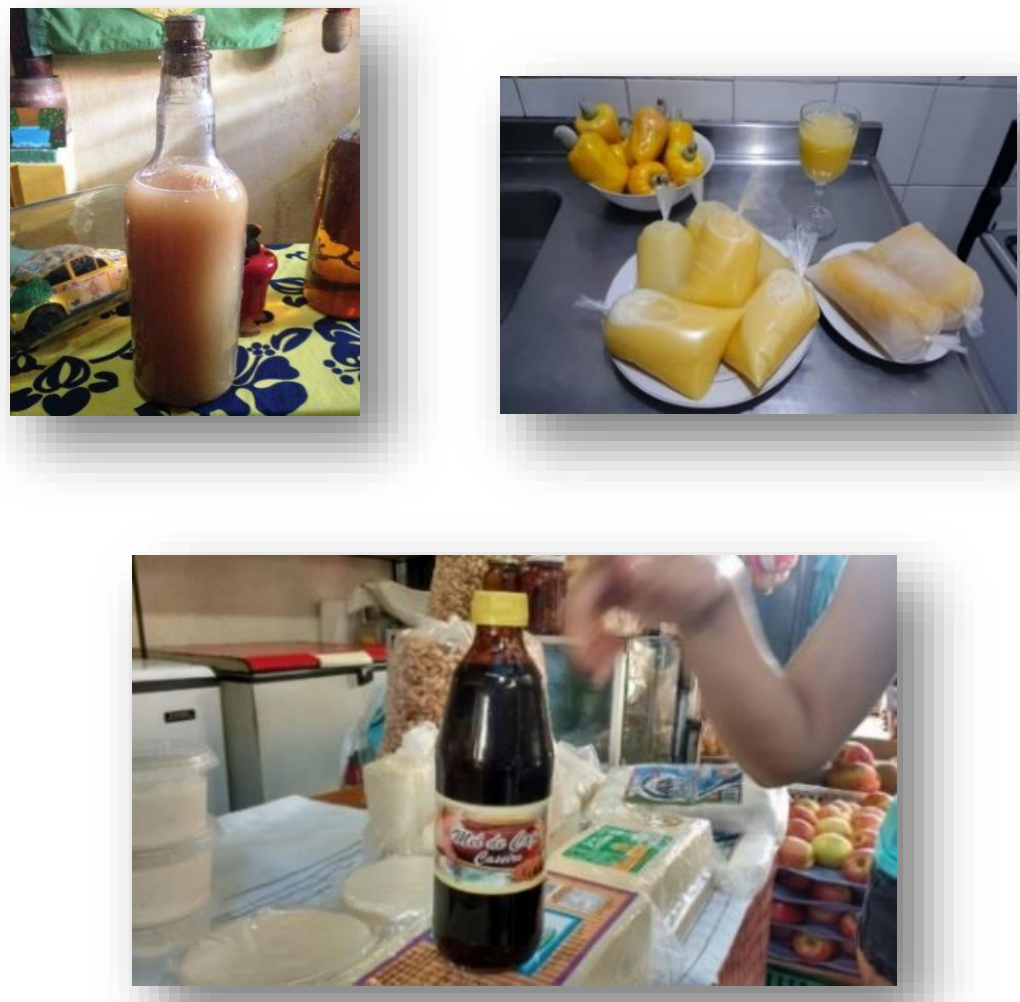

Fonte: Pesquisa empírica realizada nos meses de outubro - novembro, 2017.

Org.: RODRIGUES, Kailton Jonatha Vasconcelos, 2017.

A confeitaria nordestina é repleta de receitas que utilizam como ingrediente o caju. O pedúnculo é utilizado para fazer diversos doces: sorvetes, compotas, caju em calda ou fruta cristalizada. Vale ressaltar que a preparação de doces com caju, principalmente no período de entressafra, garante renda aos produtores, já que grande parte dos doces é produzida na propriedade dos agriculturores produtores de caju.

\section{Os circuitos espaciais da produção atrelados a castanha do caju}

A configuração do circuito espacial da produção atrelado à castanha de caju é mais complexo em comparação ao pedúnculo, entre outros, devido aos múltiplos agentes e lugares que normatizam e são articulados ao desenvolvimento dessa atividade econômica em várias fazes (produção, armazenamento, comercialização, distribuição e consumo).

De acordo com informações levantadas durante o trabalho de campo, é possível afirmar que no período da colheita é muito comum encontrar castanha armazenada nas 
A configuração territorial da cajucultura cearense: uma análise dos circuitos espaciais da produção e os círculos de cooperação da cajucultura no município de Pacajus
Kailton Jonatha Vasconcelos Rodrigues Denise Cristina Bomtempo

pequenas propriedades rurais. Geralmente os agricultores aglutinam a castanha colhida em sacos de ráfia, até que possuam quantidade suficiente para negociar com o corretor (Figura 6). Tal manejo ocorre de maneira inapropriada, tendo em vista que esse método não é nada eficaz para a manutenção da castanha, que perde sua qualidade em função da umidade a qual é exposta. Após o armazenamento de uma determinada quantidade de castanha, o produtor entra em contato com o corretor que envia até a propriedade um veículo automotor para o transporte da castanha coletada até o seu estabelecimento.

Uma vez coletada pelo corretor, a castanha é novamente armazenada em um galpão sob as mesmas condições inapropriadas. Ficam estocadas até que o corretor negocie o valor e a quantidade a ser comercializada para as indústrias processadoras de castanha.

Ilustração 6 - Armazenamento de castanha na casa de um produtor

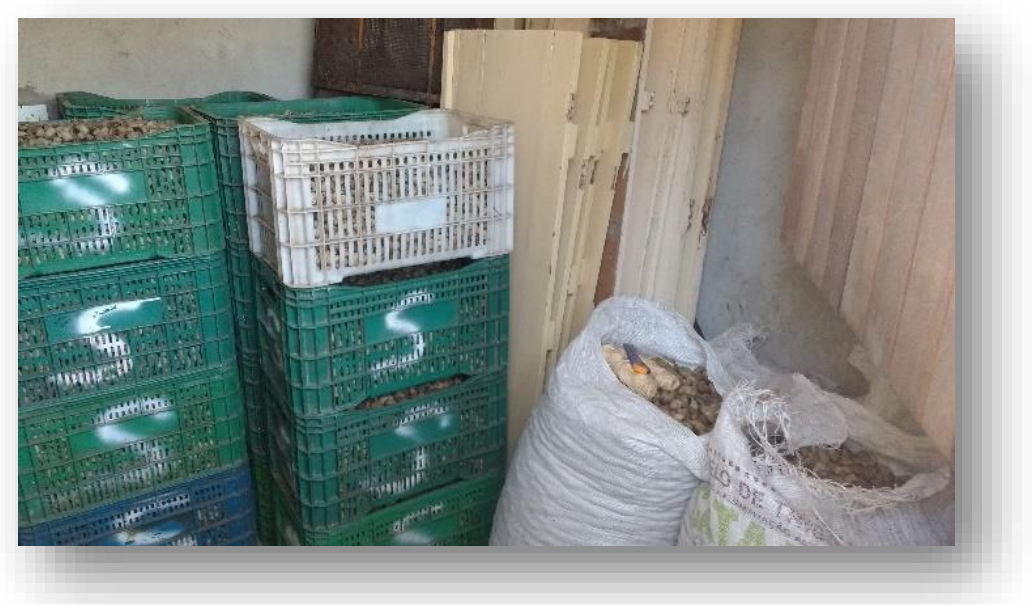

Fonte: Pesquisa empírica realizada nos meses de outubro - novembro, 2017.

Org.: RODRIGUES, Kailton Jonatha Vasconcelos, 2017.

Em se tratando dos produtores que manifestam o interesse na produção do caju, é possível identificar a aplicação de técnicas capazes de manter a saúde das plantas além de elevar a produção dos pomares, tais técnicas são oriundas de um conhecimento aprimorado, proporcionado por instituições especializadas no desenvolvimento de tecnologias que atuem exclusivamente na área da cajucultura. Ademais, os produtores dispõem de um maquinário adequado para uma colheita mais rentável, elevando grandemente o potencial produtivo de suas propriedades. Nesses ambientes, o tratamento dos cajueiros é realizado desde cedo, tendo início ainda nos primeiros meses do ano 
A configuração territorial da cajucultura cearense: uma análise dos circuitos espaciais da produção e os círculos de cooperação da cajucultura no município de Pacajus
Kailton Jonatha Vasconcelos Rodrigues Denise Cristina Bomtempo

quando geralmente os agricultores disponibilizam uma parcela do tempo entre o cultivo das culturas da safra corrente, o plantio do cajueiro e/ou sua poda e espaçamento, incluindo a limpeza do pomar, cumprindo devidamente as especificações técnicas orientadas por técnicos da EMATERCE e EMBRAPA.

$\mathrm{Na}$ sua conformação tradicional, a cajucultura apresenta elementos que a caracterizam como uma atividade marcada por relações interpessoais de caráter informal, de modo que a interação ocorre pautada por normas comportamentais referentes ao contexto em que seus agentes estão inseridos. Nesse sentido, as relações são submetidas aos graus de proximidade exercidos por seus agentes, corroboradas por um senso de valor associado a costumes e práticas tradicionais desempenhadas pelas populações responsáveis por essa atividade. Tais agentes, portanto, mantém vínculos pautados na confiança, na maioria das vezes utilizando de recursos rudimentares para o estabelecimento de contratos. Tal formato ocorre concomitantemente aos modelos mais modernos, possibilitando que os agentes possuam diferentes atuações e possam saltar de escala conforme seus interesses.

Para tanto, é necessário que se tenha compreensão dos agentes envolvidos nesta configuração, são eles: o agricultor, que pode ser o pequeno ou médio produtor rural; o corretor, ou popularmente conhecido como atravessador, figura chave para a compreensão desta intrínseca cadeia de relações; e as unidades de processamento, sejam elas as fábricas ou mini fábricas. Conjuntamente, existem agentes de menor visibilidade cuja função está contida dentro dessa teia de relações exercendo papéis bastante específicos, tais como os tradicionais "assadores”, responsáveis pela torrefação artesanal da castanha de caju e posterior comercialização para os mercados locais; e os ateliês, pequenas oficinas que aplicam um sistema de trabalho artesanal para a realização do descastanhamento e limpeza da amêndoa, geralmente subcontratadas por empresas de médio porte para uma operacionalização de baixo custo e em um curto período de tempo.

Durante os primeiros meses do ano, a maior parte dos elementos que integram a cajucultura permanece sem atividades, com exceção das grandes unidades industriais que se utilizam da castanha armazenada ao longo da safra anterior, estas, continuam funcionando até que seus estoques estejam esgotados e passem a comprar ainda mais castanha, o que só acontece na época da safra. Os demais elementos estão ainda mais vinculados à colheita, uma vez que estes dependem demasiadamente da coleta e venda da 
A configuração territorial da cajucultura cearense: uma análise dos circuitos espaciais da produção e os círculos de cooperação da cajucultura no município de Pacajus
Kailton Jonatha Vasconcelos Rodrigues Denise Cristina Bomtempo

castanha. Os agricultores colhem, separam e armazenam a castanha, os corretores compram essa castanha, estabelecendo um preço baseado no montante solicitado pelas empresas, em seguida recolhem a castanha comprada que logo é direcionada às fábricas para que sejam pesadas e compradas.

Nas fábricas, as castanhas são beneficiadas e comercializadas no mercado internacional da amêndoa. Os grandes produtores mundiais, entre eles o Brasil, agem enquanto fornecedores do produto que será processado para consumo final no país de destino. Se o destino do produto for o mercado de aperitivos, a amêndoa passa por torra e salga. Se o destino for para chocolates e sobremesas, a amêndoa á quebrada e utilizada in natura ou torrada. O Organograma 1 permite entender os destinos do caju. Ainda, vale ressaltar que todas as fases e todos os agentes estão presentes no município de Pacajus.

Organograma 1 - Destino dos produtos do caju

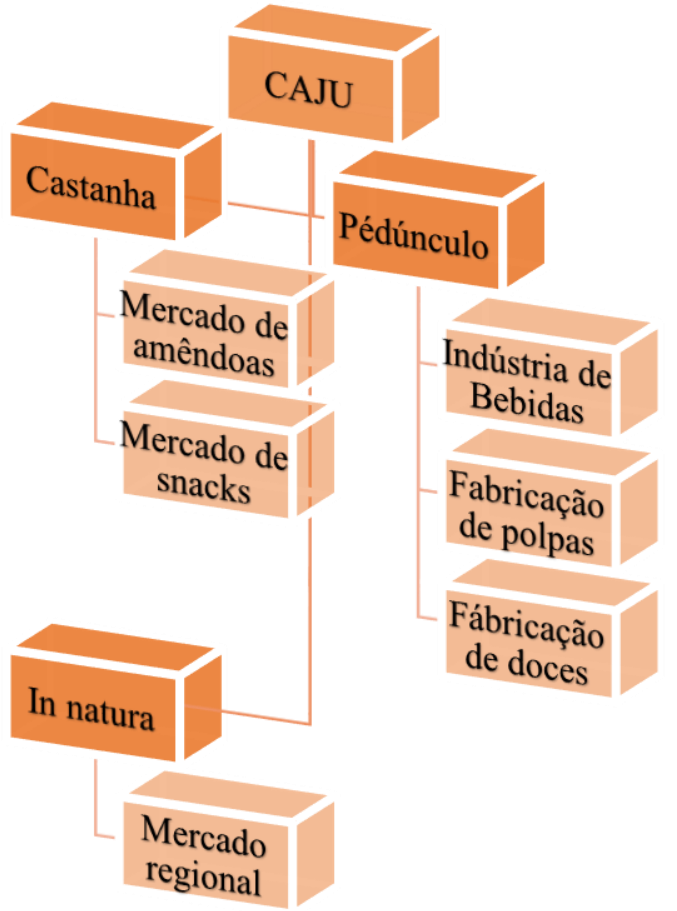

Fonte: Pesquisa empírica realizada nos meses de outubro - novembro, 2017.

Org.: RODRIGUES, Kailton Jonatha Vasconcelos, 2017.

O Organograma 01 esboça o direcionamento tomado por cada uma das vertentes da produção do caju, evidenciando as destinações conforme o segmento produtivo. É notório o alcance tomado pela castanha de caju, que carrega consigo o status de 
A configuração territorial da cajucultura cearense: uma análise dos circuitos espaciais da produção e os círculos de cooperação da cajucultura no município de Pacajus
Kailton Jonatha Vasconcelos Rodrigues Denise Cristina Bomtempo

commodity e possui maior valor econômico dentro da cajucultura, abaixo desta o pedúnculo prevalece, amparado pela ampla gama de produtos possíveis; por último e não menos importante, o caju in natura, ou de mesa, que estabelece uma relação intimamente regional, cujo o valor consiste na sua comercialização nas feiras e mercados.

A dinamicidade das relações provenientes deste modelo de cajucultura, estão diretamente atreladas as formas que caracterizam a agricultura no estado do Ceará, marcados por um passado que privilegiou a cultura do algodão em detrimento das produções historicamente estabelecidas, aspecto esse que será melhor trabalhado no decorrer do texto.

\section{Os agentes articuladores dos circuitos produtivos e aos círculos de cooperação da cajucultura em Pacajus}

A cajucultura em Pacajus e na maioria dos principais municípios produtores do Ceará vem passando por um intenso processo de modernização, consequência da interrelação mantida entre agentes públicos e privados, que compõem o círculo de cooperação da produção de caju. Almejando uma maior presença no circuito produtivo em escala nacional e majoritariamente a nível internacional, tais agentes dinamizam os direcionamentos e as normatizações do mercado de modo que cheguem até os produtores, estimulando o desenvolvimento técnico-científico e melhoramento das práticas agrícolas no intuito de atingir uma maior produtividade e qualidade.

O círculo de cooperação da cajucultura no Ceará é composto pela: Embrapa Agroindústria Tropical, vertente da EMBRAPA, responsável pelo desenvolvimento de pesquisas que viabilizem uma produção caracterizada por elementos técnico-científicos atribuídos ao caju, manifestadas pelo melhoramento genético e manutenção dos pomares para uma produtividade de melhor qualidade; a EMATECE, responsável pela assistência técnica aos agricultores e suas organizações, divulgando e executando políticas governamentais para o setor agrícola do estado; a ADECE - Agência do Desenvolvimento do Estado do Ceará, responsável pela execução da política de desenvolvimento econômico, industrial, comercial, de serviços, agropecuário e de base tecnológica, que no caso da cajucultura, atua a partir da Câmara Setorial do Caju, que trabalha na perspectiva da identificação de gargalos e na realização de atividades e projetos articulados as políticas de desenvolvimento da cajucultura no estado; as Agências de fomento e 
A configuração territorial da cajucultura cearense: uma análise dos circuitos espaciais da produção e os círculos de cooperação da cajucultura no município de Pacajus
Kailton Jonatha Vasconcelos Rodrigues Denise Cristina Bomtempo

financiamento, como a Fundação Banco do Brasil e o Banco do Nordeste, que desenvolveram os projetos de mini fábrica de beneficiamento de castanha de caju e oferecem linhas de crédito com juros baixos, prazos acessíveis e bônus para quem paga em dia, para os pequenos e médios produtores; as pequenas e médias empresas beneficiadoras de castanha, que dinamizam e articulam o setor através da compra e distribuição da castanha a nível regional e nacional; além dos governos estadual e municipal que desenvolvem políticas públicas para o aquecimento do setor, realizando eventos de incentivo à modernização, como atividades festivas e exposições agropecuárias; tais como a Caju fest em Pacajus e a Frutal em Fortaleza; além de elementos simbólicos que estabelecem um vínculo tradicional e histórico entre o caju e o município, tal qual a Lei 13.611, de 28 de junho de 2005, que reconhece o município de Pacajus como a capital do caju do estado do Ceará.

Essa gama de agentes, seja de caráter público ou privado, conduzidos pelos interesses mercadológicos, despertam processos que culminam no desenvolvimento de novas técnicas para a cajucultura. Eventualmente, tais técnicas chegaram aos produtores, ainda que de uma forma deficitária, tendo em vista as dificuldades de aplicação dessas técnicas na configuração dos circuitos. Logo, incorporam os produtores numa faceta mais modernizada dentro do circuito espacial de produção do caju, inserindo a castanha de caju de Pacajus no mercado nacional e internacional.

Nessa perspectiva, a atuação de Pacajus enquanto intersecção no circuito produtivo da cajucultura ocorre durante as primeiras fases do processo, durante a produção agrícola e o beneficiamento da castanha, regulada pelo incentivo a modernização das práticas e a execução das normas de mercado. Em sua grande maioria os produtores são responsáveis pelo beneficiamento da castanha de caju, mas quando inserido nessa lógica modernizante passam a ser também responsáveis pelo processamento, isso através das cooperativas e mini fábricas, distribuídas pelas áreas rurais do município, para depois inserir a castanha num mercado que atende a uma demanda nacional ou até mesmo internacional.

Dentro da lógica do circuito espacial da cajucultura, existe ainda outro agente de destaque presente em Pacajus, o corretor ou intermediário. Este estabelece a conexão entre os produtores e as grandes unidades de processamento, através da compra 
A configuração territorial da cajucultura cearense: uma análise dos circuitos espaciais da produção e os círculos de cooperação da cajucultura no município de Pacajus

da castanha diretamente do agricultor através de vínculos informais e revendendo para as grandes processadoras industriais.

\section{CONSIDERAÇÕES FINAIS}

Ao lançar o olhar para a compreensão do território e suas implicações no espaço é perceptível a necessidade de enxergar as transformações sociais verdadeiramente ocorridas ou as que ainda irão ocorrer; de ampliar o entendimento sobre as organizações, as redes, os agentes, as relações e de estimular reflexões acerca dos efeitos dessas ações sobre a estrutura social. Logo, é possível perceber que nas conexões manifestadas no território estão presentes as sobreposições de camadas que definem os circuitos espaciais da produção, tendo em vista que as ações desenroladas suscitam práticas e refletem diversas conexões que mobilizam todo desdobramento dos circuitos produtivos.

O universo da cajucultura, não está alheio a esta conformação, portanto reúne uma gama de elementos que a tornam uma complexa estrutura, organizada e distribuída ao longo de um extenso território produtivo cujas fronteiras não se limitam a delimitações de municípios ou estados, mas a fatores políticos e sobretudo econômicos. Engendramento que compõem uma lógica historicamente determinada com presença simbólico cultural bastante evidentes. Tal condição exerce influência diferenciada nas práticas mantidas no decorrer da produção e comercialização de uma fruta que desperta o interesse não só pela sua potencialidade econômica, mas também pela sua carga emblemática para o nordestino. A dificuldade da realização da pesquisa é resultado da grandiosidade da temática, que abarca uma série de processos, fenômenos e agentes que a priori não se conectam, mas após um olhar mais atento, evidenciam suas participações.

Nesse sentido, a partir do que foi levantado, podemos inferir que o município de Pacajus se tornou lócus de lógicas capitalistas determinadas pela atuação de agentes econômicos em função de seu papel como um importante nó na rede de operações logísticas no território. Expressando assim, uma quantidade relevante de agentes públicos e privados vinculados ao setor. Portanto, o papel do município é de extrema relevância no contexto da dinâmica econômica atrelada a cajucultura no estado do Ceará, sobretudo enquanto uma área de intersecção de nós estratégico em sua região na promoção da circulação da castanha de caju. 
A configuração territorial da cajucultura cearense: uma análise dos circuitos espaciais da produção e os círculos de cooperação da cajucultura no município de Pacajus
Kailton Jonatha Vasconcelos Rodrigues Denise Cristina Bomtempo

Nota

${ }^{1}$ Além de Milton Santos, outros pesquisadores também trabalharam com os circuitos espaciais da produção e os círculos de cooperação. São eles: a) ELIAS, Denise. Globalização e Agricultura: a região de Ribeirão Preto SP. São Paulo: Edusp, 2003; b) ARROYO, María Mônica. Território Nacional e mercado externo: uma leitura do Brasil na virada do século XXI. Tese de Doutorado defendida no Programa de Pós-Graduação em Geografia Humana da FFLCH/USP. São Paulo: FFLCH, 2001. c) GRIMM, Flávia Christina Andrade. Uso do território e coexistências de empresas de refrigerantes no Brasil. Dissertação de Mestrado defendida no Programa de PósGraduação em Geografia Humana da FFLCH/USP. São Paulo: FFLCH, 2002. d) PEREIRA Jr. Edilson Alves. Industrialização e reestruturação do espaço metropolitano: reflexões sobre o caso de Horizonte-Pacajus. Fortaleza: EdUECE, 2005. e) BOMTEMPO, Denise Cristina. Dinâmica territorial, atividade industrial e cidade média: as interações espaciais e os circuitos espaciais da produção das indústrias alimentícias de consumo final instaladas na cidade de Marília - SP. Presidente Prudente: [s.n], 2011, 455 p.

\section{REFERÊNCIAS}

Agência de Desenvolvimento do Estado do Ceará - ADECE "Câmara setorial do caju Ceará. In: http://www.adece.ce.gov.br/index.php/cajucultura. Acesso em 30/4/2019.

BOMTEMPO, D. C. Dinâmica territorial, atividade industrial e cidade média: as interações espaciais e os circuitos espaciais da produção das indústrias alimentícias de consumo final instaladas na cidade de Marília - SP. Tese de Doutorado.

PPGG/UNESP/Presidente Prudente: Presidente Prudente, 2011.

BOMTEMPO, D. C.; BATISTA, E. da S. Cajucultura cearense: produção familiar em Beberibe. In: Revista GeoNordeste, São Cristóvão, Ano XXIX, n. 1, p. 145-159, Jan./Jun. 2018. ISSN: 2318-2695.

CASTILLO, R.; FREDERICO, S. Espaço geográfico, produção e movimento: uma reflexão sobre o conceito de circuito espacial produtivo. Sociedade \& Natureza, Uberlândia, v. 3, n. 22, p. 461-474, dez. 2010. Disponível em:

<http://www.seer.ufu.br/index.php/sociedadenatureza/article/view/11336>. Acesso em 20 junho 2017.

GOMES, F. de. A. Philomeno. Centenário de Nascimento de Pedro Philomeno Ferreira Gomes (1888-1988). Fortaleza, s. ed., 1988.14p.

LEITE, L. A. de S. A agroindústria de caju no Brasil: políticas públicas e transformações econômicas. Fortaleza: EMBRAPA-CNPAT, 1998. 195 p.

MORAIS, J. O. de; FREIRE, G. S. Sá; PINHEIRO, L. de S.; SOUZA, M. J. de; CARVALHO, A. M. de; PESSOA, P. R. S.; OLIVEIRA, S. H. In: Dieter Muehe. (Org.). Erosão e Progradação do Litoral Brasileiro. Rio de Janeiro: Programa de Geologia e Geofísica Marinha-PGGM (no prelo), 2006, v. 198-200.

PEREIRA JR., Ed. A. Metropolização e novos arranjos espaciais: uma discussão a partir do processo de industrialização em Horizonte e Pacajus (CE). 2002, Revista da Casa da Geografia de Sobral, vol. 4/5. pp. 93-99. 
A configuração territorial da cajucultura cearense: uma análise dos circuitos espaciais da produção e os círculos de cooperação da cajucultura no município de Pacajus
Kailton Jonatha Vasconcelos Rodrigues Denise Cristina Bomtempo

SANTOS, M. Circuitos espaciais da Produção: um comentário. In: SOUZA, Maria Adélia A. de (Org.). A construção do Espaço. São Paulo: Nobel, 1986.

A Natureza do Espaço: técnica e tempo / razão e emoção. $4^{a}$ Edição. Editora Hucitec, São Paulo, 1996/1999/2009, p. 186 - 207.

Metamorfoses do espaço habitado: Fundamentos Teóricos e

Metodológicos da Geografia. São Paulo: Hucitec, 1988.136p.

SANTOS, Milton \& SILVEIRA, Maria Laura da. Brasil: território e sociedade no início do século XXI. Rio de Janeiro: Record, 2001.

SERRANO, L. A. Lopes; PESSOA, P. F. A. de P. Aspectos econômicos da cultura do cajueiro. In: Luiz Augusto Lopes Serrano. (Org.). Sistema de Produção do CAJU. 2ed.Brasília-DF: Embrapa Informação Tecnológica, 2016, v. 1, p. 2-10.

VIDAL, M. de F. Cajucultura nordestina continua em declínio. Caderno setorial ETENE, ano 2, n 22, dezembro, 2017, 11p. 